\title{
Influencia de las características petrofísicas en la penetración de consolidantes en rocas monumentales porosas
}

\author{
Influence of petrographical characteristics \\ in the penetration of consolidants \\ in porous building stones
}

Fecha de recepción: 14-V-93.

\author{
R. M. ESBERT y F. DÍAZ-PACHE \\ Departamento de Geología (Petrología) \\ Universidad de Oviedo. 33080 OVIEDO (ESPAÑA)
}

\section{RESUMEN}

En este trabajo se estudia la capacidad de penetración de un tratamiento consolidante, de uso frecuente en restauración - silicato de etilo-, aplicado a dos rocas monumentales con porosidades y configuraciones del sistema poroso diferentes; la caliza de Hontoria (Burgos) y la dolomía de Laspra (Asturias). Se pretende tener una idea precisa de las relaciones entre: modo de aplicación del producto, profundidad de penetración y cambios inducidos en la porosidad y configuración del sistema poroso de las rocas mencionadas.

La técnica empleada para controlar, tanto la profundidad de penetración del tratamiento, como su influencia en los espacios vacios de la piedra, ha sido la porosimetría de mercurio.

Los resultados obtenidos revelan que no siempre la roca más porosa es la que mejor admite el tratamiento, y que la penetración de un producto de este tipo en la roca, está condicionada también por las caracteristicas petrofísicas de la misma.

\begin{abstract}
$S U M M A R Y$
This paper describes a study of the penetration capacity of a consolidant frequently used in restoration -ethyl silicate- applied to two monumental stones with different porosities and pore geometries: the Hontoria limestone (Burgos) and the Laspra dolomite (Asturias). The relation between mode of application and penetration into the rock, and changes in porosity and pore geometry in the treated rocks, are discussed.
\end{abstract}

Mercury porosimetry has been employed to measure both the depth of penetration of the treatment and its influence on the void spaces in the rock.

The results obtained reveal that the most porous rock is not always that which most easily admits the treatment solution, and that the penetration of a treatment product is also influenced by the petrophysical properties of the rock.

\section{INTRODUCCIÓN}

"El éxito de la aplicación de un producto de tratamiento depende, en gran medida, de la profundidad de penetración y de su distribución en el interior de los espacios vacios de la piedra" (1). Por lo tanto, conocer dicha profundidad de penetración y las características del material rocoso que la controlan parece fundamental a la hora de valorar la eficacia del mismo, una vez aplicado.

\section{INTRODUCTION}

"The success of a treatment product depends, to a large extent, on the depth of penetration and its distribution in the interior of the stone" (1). An understanding of this depth of penetration and of the characteristics of the rock which control the penetration, are, therefore, fundamental in evaluating the effectiveness of the treatment once applied. 
A este respecto debe destacarse que, con relación a la consolidación, los productos diseñados para tal fin deben penetrar en la piedra de modo que no alcancen únicamente la zona alterada, sino también parte de la sana. En caso contrario, al polimerizar el producto, entre la parte afectada y aquella que no lo está, se puede generar una superficie de discontinuidad física, que podría propiciar el desprendimiento de la capa que contiene el tratamiento, con lo cual se inducirían daños mayores que los que se intenta reparar.

También es importante conocer las variaciones en la porosidad y configuración del sistema poroso de las piedras tratadas con respecto a las no tratadas, puesto que las propiedades relacionadas con la captación, pérdida y transferencia de humedad por el interior de la piedra, dependen del número de espacios vacíos y de su geometría. Ambos aspectos inciden sobre la acción de agentes alterantes tan importantes como, por ejemplo, el hielo y las sales, condicionando la durabilidad de los sistemas piedra-tratamiento.

En este trabajo, y a modo de ejemplo experimental, se realiza el seguimiento de la penetración de un tratamiento consolidante — silicato de etilo - aplicado a dos variedades rocosas con distintas porosidades y configuraciones porosas. Se trata de las piedras de Hontoria y Laspra, muy utilizadas en el patrimonio arquitectónico español. El trabajo intenta corroborar la hipótesis de que no sólo la porosidad sino también la geometría del sistema poroso controlan dicha penetración.

\section{MATERIALES PÉTREOS UTILIZADOS}

Se han seleccionado dos tipos de rocas carbonatadas con texturas muy diferentes, lo cual condiciona que tanto su volumen de poros, como la configuración tridimensional de los mismos sean claramente distintos: la caliza de Hontoria y la dolomía de Laspra.

Ambas, además de cumplir los requisitos antes expuestos, son rocas con un uso muy relevante en el patrimonio de Castilla y León y de Asturias, respectivamente.

La caliza de Hontoria es una caliza bioclástica compacta, de colores claros blanco-grisáceos (Fig. 1), con granos minerales y restos fósiles heterométricos. Presenta un moteado debido a óxidos de hierro, así como pequeños núcleos recristalizados (geodas). Su composición mineralógica, determinada por difractometría de Rayos X, es de $99,6 \%$ de calcita y $0,4 \%$ de cuarzo.
In this respect, it must be emphasised that the products designed to consolidate the stone must penetrate the material so as to reach not only the altered zone but also the unaltered rock. If this requirement is not achieved a physical discontinuity between the treated and untreated zone may be formed when the product polymerisizes. This can bring about a detachment of the treated layer, giving rise to major damage which must then be repaired.

It is also important to understand variations in porosity and the geometry of the pore system of the treated and untreated rock. This is so because the properties related to the uptake, loss and transfer of moisture in the rock interior depend upon the number of spaces and their geometry. These properties also directly control the action of alteration agents such as ice and salt crystallisation, which also influence the durability of rock treatment systems.

In this paper, as an experimental example, the penetration of a consolidant (ethyl silicate) is described in two rock types with different porosities and pore geometries: the Hontoria and Laspra stones, used widely in the architectural heritage of Spain. The paper seeks to corroborate the hypothesis that it is not only the porosity but also the pore geometry which control, to a large extent, the penetration of consolidants.

\section{ROCK MATERIALS TESTED}

Two types of carbonate rock with very different textures have been selected, as representing materials with clearly distinct pore volumes and three dimensional pore geometries: the Hontoria limestone and the Laspra dolomite.

Both of these rocks not only satisfy the above mentioned experimental requirements but are also very important in the architectural heritage of Castilla y León and Asturias, respectively.

The Hontoria limestone is a compact limestone, with clean greyish-white coloration (Figure 1). The rock contains fossil remains of variable size, and has a mottled appearance due to iron oxides and small recrystallised geodes. The mineralogical composition of the rock, determined by $X$-ray diffraction, is $99,6 \%$ calcite and 0,4\% quartz. 


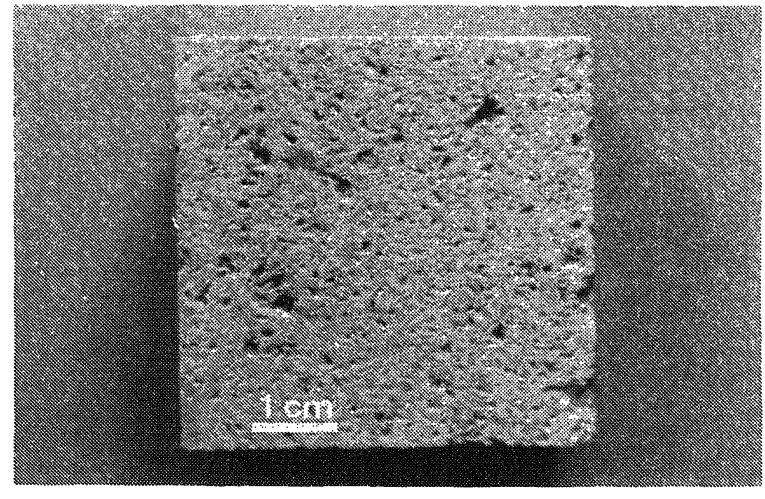

Fig. 1.-Aspecto macroscópico de la caliza de Hontoria. Destaca la presencia de los poros visibles a esta escala.

Fig. 1.-Macroscopic appearance of the Hontoria limestone. Note the presence of pores, visible even on this scale.

Ha sido empleada en la construcción de las Catedrales de Burgos y León, así como en diversos monumentos de Castilla y León.

Sus propiedades físicas aparecen recogidas en diversos trabajos (2 y 7 ).

Su porosidad abierta accesible al mercurio oscila entre $20,5 \%$ y $23,3 \%$, correspondiendo la mitad de dicho valor a porosidad libre y la otra mitad a porosidad atrapada (3), como se observa en la figura 2. La configuración del sistema poroso de esta roca está muy marcada por la heterometría granular, que genera grandes espacios vacíos conectados por conductos de radio mucho más pequeño (Fig. 3).

La dolomía de Laspra tiene un color blanquecino y un aspecto masivo y homogéneo (Fig. 4). Su textura es micrítica -tamaño de grano inferior a 4 micras - y su composición mineralógica es de un $95,85 \%$ de dolomita y un $4,15 \%$ de cuarzo, con pequeñas concentraciones de filosilicatos.

Esta piedra se ha utilizado en la construcción de la Catedral de Oviedo (4), y en otros monumentos prerrománicos de Asturias (5).

Sus propiedades físicas pueden encontrarse en diversos trabajos (6-7).

Es una roca microporosa - poros con radios de acceso menores de 7,5 micras, según

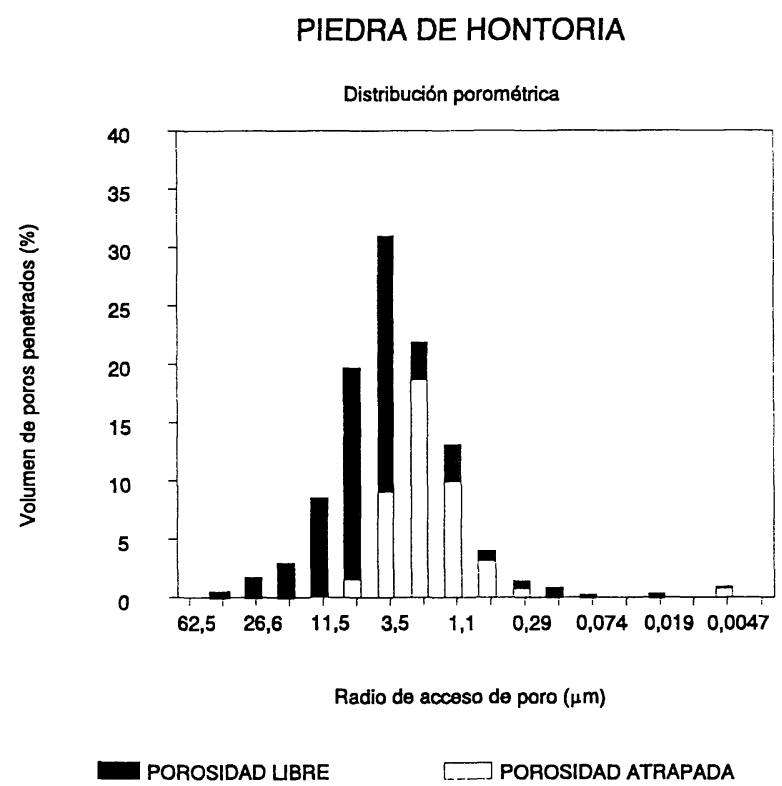

Fig. 2.- Histograma de la distribución porométrica de la caliza de Hontoria. El tamaño medio de radio de acceso de poro se situa alrededor de las 3,5 micras.

Fig. 2.-Histogram showing the distribution of pore throat radii in the Hontoria limestone. The mean pore throat radius is around $3.5 \mu \mathrm{m}$.

The rock has been used in the construction of the cathedrals of Burgos and León and in several monuments of "Castilla y León".

The physical properties of the Hontoria limestone have been described by Marcos et al. (2).

The open porosity accessible to mercury varies between $20,5 \%$ and $23,3 \%$. Half of which is made up of connected porosity and the other half unconnected (3), as can be seen in Figure 2. The pore geometry of the rock is characterised by a inequigranular texture which gives rise to large voids connected by very small pore throats (Figure 3).

The Laspra dolomite has a whitish colour and is massive and homogeneous (Figure 4). The rock has a micritic texture -grain size $<4 \mu \mathrm{m}$ - and its mineralogical composition is $95.85 \%$ dolomite and $4.15 \%$ quartz, with small concentrations of phyllosilicates.

The rock has been used in the construction of Oviedo Cathedral (4) and other pre-Romanic monuments of Asturias (5).

The physical properties of the Laspra dolomite have been described in several papers (6-7).

By mercury porosimetry is a microporous rock $-r<7.5 \mu \mathrm{m}-$ (Figures 5 and 6), with a porosity 


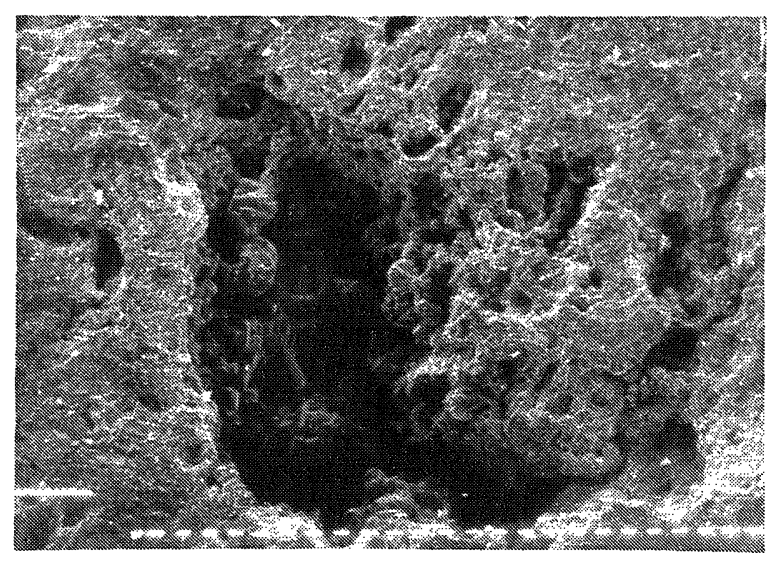

Fig. 3.-Aspecto al M.E.B. (Microscopio Electrónico de Barrido) de los espacios vacios de la piedra de Hontoria. Se trata de una piedra con poros grandes, unidos por conductos más pequeños. (x 40). Cada micromarcador son 100 micras.

Fig. 3.-S.E.M. (Scanning Electron Microscope) image of the void spaces of the Hontoria stone. This is a rock with large pores connected by narrow pore throats $(x 40)$. Scale $=100 \mu \mathrm{m}$.

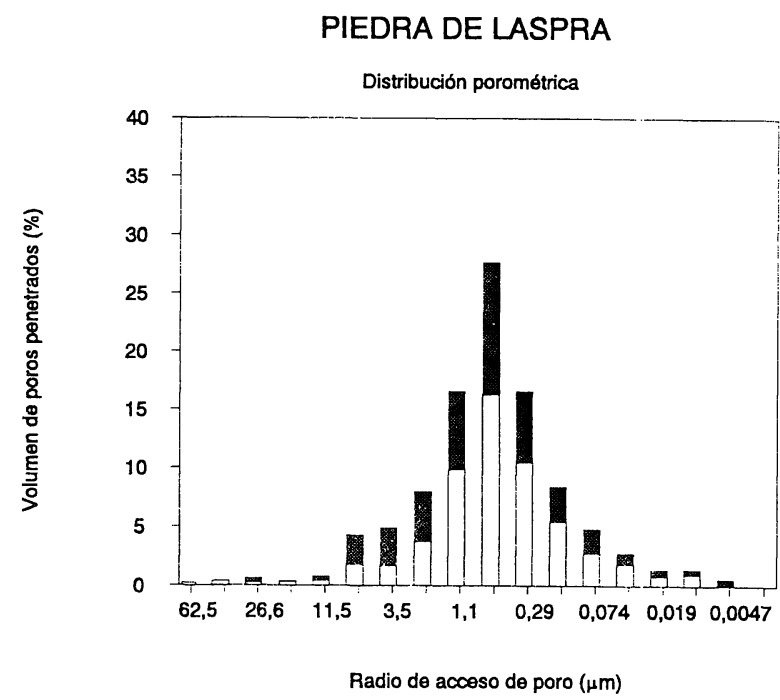

POROSIDAD LIBRE POROSIDAD ATRAPADA

Fig. 5.-Histograma de la distribución porométrica de la piedra de Laspra. El tamaño medio de radio de acceso de poro se situa alrededor de las 0,5 micras.

Fig. 5.- Histogram showing the distribution of pore throat radii in the Laspra stone. The mean pore throat radius is around $0.5 \mu \mathrm{m}$.

porosimetría de mercurio- (Figs. 5 y 6), con una porosidad accesible de alrededor del $36,5 \%$, bastante mayor, por tanto, que la que muestra la piedra de Hontoria.

Ambas rocas, debido a su naturaleza sedimentaria, pueden presentar variaciones en los valores de la porosidad aqui presentados.

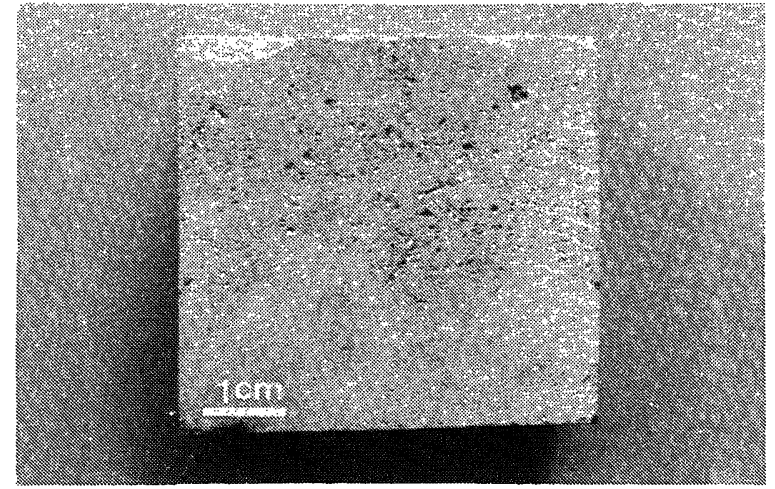

Fig. 4.-Aspecto macroscópico de la dolomía de Laspra. Es una roca más homogénea que la caliza de Hontoria y con poros más pequeños.

Fig. 4.-Macroscopic appearance of the Laspra dolomite. This is a more homogeneous rock than the Hontoria limestone with smaller pores.

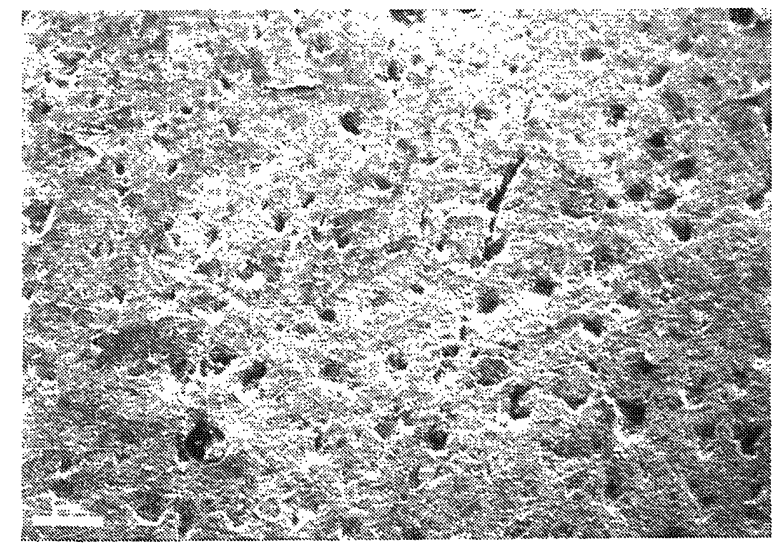

Fig. 6.-Aspecto al MEB (Microscopio Electrónico de Barrido) de los espacios vacios de la piedra de Laspra (Esbert y Marcos, 1983). Se observa la presencia de un gran número de poros de tamaño pequeño y uniforme. (x 60). El marcador son $0,25 \mathrm{~mm}$.

Fig. 6.-S.E.M. (Scanning Electron Microscope) image of the void spaces of the Laspra stone (Esbert and Marcos, 1983). The presence of a large number of small uniform pores can be observed (x 60). Scale $=0.25 \mathrm{~mm}$.

around $36,5 \%$, rather larger than that of the Hontoria limestone.

Both rocks, because of their sedimentary nature, can exhibit appreciable variations in their pososity values, which must be taken into account in their study. 


\section{TRATAMIENTOS: PREPARACIÓN Y MODO DE APLICACIÓN}

Se ha aplicado, sobre ambos tipos rocosos, un producto consolidante, para aumentar el grado de cohesión entre los minerales de la roca.

Concretamente ha sido silicato de etilo (Tegovakon V), que desde el punto de vista químico se engloba dentro de los productos de naturaleza sílico-orgánica. Se trata de un éster de ácido silícico, que una vez aplicado sobre la piedra reacciona con el agua de la misma y la humedad del ambiente, formando un gel de sílice y liberando alcohol.

Este producto final precipitado -gel de síliceocupa menor volumen que el líquido de tratamiento, por lo cual no rellena los poros por completo.

El consolidante se ha diluido con alcohol etílico, en la proporción 1:10, con el fin de consiguir una mayor penetración.

El tratamiento ha sido aplicado con pincel, intentando acercarse a las condiciones que suelen darse en la práctica. Además, y para lograr un patrón de comportamiento, se ha aplicado por capilaridad sobre probetas cúbicas de $5 \mathrm{~cm}$ de arista.

La aplicación por capilaridad duró 7 días y consistió en tener las probetas sobre papeles de filtro empapados en solución tratante, la cual cubría unos $5 \mathrm{~mm}$ de la piedra, manteniéndose esta altura constante. Las probetas fueron protegidas de la luz y aisladas del ambiente.

El tratamiento con pincel se aplicó sobre una de las caras de las probetas en 3 sesiones, separadas entre sí unas 24 horas, dejando las probetas protegidas de la luz.

Las muestras antes del tratamiento se mantuvieron en una cámara climática con una humedad del $75 \%$ y una temperatura de $25^{\circ} \mathrm{C}$, hasta que alcanzaron un peso constante.

Posteriormente, para controlar la evaporación del producto, las probetas se envolvieron con un film de poliuretano por cinco de sus caras, de modo que el contacto con el ambiente se producía sólo por la cara tratada. Se mantuvieron así durante 70 días, tiempo necesario para la completa reacción del silicato de etilo, controlando el peso de las mismas permanentemente.
TREATMENTS: PREPARATION AND APPLICATION

A consolidant has been applied to each rock type studied to improve the cohesion between the minerals present in the rock.

Specifically, ethyl silicate (Tegovakon V), which, from the chemical point of view, belongs to the silico-organic group of products. The material is an ester of silicic acid which, once applied to the rock, reacts with the water in the rock and in the environment to form a silica gel, releasing alcohol.

The material finally produced is a silica gel which occupies a smaller volume than the treatment solution, thus leaving part of the pore space unfilled.

The consolidant is diluted with ethyl alcohol (a dilution of 1:10) in order to obtain optimun penetration.

The treatment has been applied using $5 \mathrm{~cm}$ cubes, in two ways: a) with a brush, trying to simulate the conditions likely to be encountered in situ; b) by capillarity, in order to observe the pattern of behaviour.

The application by capillarity lasted 7 days during which the cubes were placed on filter paper saturated with the treatment solution which covered about $5 \mathrm{~mm}$ of the samples; this level was maintained constant. The samples were protected from the light and isolated from the environment.

In the case of application by brush, the treatment solution was applied to one face of each sample cube three times, each application being separated by 24 hours, again protecting the samples from the light.

Before treatment, the sample cubes were kept in a climatically controlled environment with a humidity of $75 \%$ and a temperature of $25^{\circ} \mathrm{C}$ until they attained a constant weight.

Later, in order to control the evaporation of the treatment solution, five faces of each sample cube were wrapped in polyurethane film to ensure that only the treated face was in contact with the environment. This was maintained for 70 days, allowing the complete reaction of the ethyl silicate; during this time the weight of the samples was checked at predetermined intervals. 
Este control de los pesos de las probetas permitió observar que los mismos no se estabilizan hasta pasados al menos 40 días; dándose el caso, en la dolomía de Laspra tratada por capilaridad, que a los 70 días aún no se había alcanzado la estabilidad.

Este hecho debe tenerse presente cuando se aplican estos tratamientos a materiales pétreos, y contrastarlo con las indicaciones de las casas comerciales. Éstas indican que los productos de esta naturaleza sin disolver, tal como se suelen expender, alcanzan la estabilidad a los 21 días. El control del tiempo de estabilización del consolidante es particularmente importante en aquellos casos en los que después se proceda a la protección de la piedra.

\section{ANÁLISIS DE LAS VARIACIONES DEL SISTEMA POROSO}

\section{Metodología de trabajo}

La porosidad y variaciones en la configuración del sistema poroso de la roca tratada a distintas profundidades con respecto al de la roca no tratada, han sido determinadas mediante porosimetría por inyección de mercurio, realizando ensayos porométricos seriados cada $5 \mathrm{~mm}$, a partir de la cara de aplicación del tratamiento, y hacia el interior.

Cada unidad ensayada se ha tomado de acuerdo con el modelo presentado en la figura 7 , que representa el corte en alzado a una probeta.

Esta técnica permite, de forma indirecta, determinar la máxima profundidad de penetración del tratamiento para cada piedra y modo de aplicación.

\section{Porosimetría por inyección de mercurio}

Los fundamentos físicos de esta técnica están desarrollados en gran número de trabajos (3 y 8-11).

Se han realizado ensayos desde la superficie de aplicación del producto hasta llegar a la zona de la roca que presentaba una porosidad igual a la original. De este modo el número de ensayos ha sido distinto para cada tipo de sistema piedratratamiento.

También se han realizado diversos ensayos porosimétricos en las piedras sin tratar, con el fin de conocer la porosidad de partida y el grado de variabilidad porométrica de las rocas estudiadas.
Monitoring of the weight of the treated cubes revealed that it did not stabilise until $\mathbf{4 0}$ days into the test, the Laspra dolomite treated by capillarity failing to reach a constant weight (that is, the reaction being incomplete) even after 70 days.

This must be considered when applying treatments to the stones, and contrasts with the claims of manufacturers that the treated stone stabilises (without dissolvent) in 21 days.

\section{ANALYSIS OF VARIATIONS IN THE PORE SYSTEM}

\section{Methodology}

The porosity and variations in the geometry of the pore system of the treated rock have been determined at different depths using serial pososimetry measurements at $5 \mathrm{~mm}$ intervals from the treated surface towards the interior, in order to compare the treated and untreated rock. Each sample cube has been cut according to the model shown in Figure 7.

This technique permits the indierect determination of the maximun penetration of the treatment solution for each rock type and for each mode of application.

\section{Mercury porosimetry}

The physical basis for the mercury porosimetry employed has been described in many papers $(3,8-11)$.

Measurements have been carried out from the treated surface into the rock as far as the unmodified rock. In this way, the number of tests has been different for each rock-treatment system.

Porosimetry measurements have also been carried out on untreated rock in order to understand the porosity of the original rock and the variability in porosity of the rocks studied. 
Los resultados numéricos obtenidos se recogen en la tabla I y sus expresiones gráficas en la figura 8 (a-d).

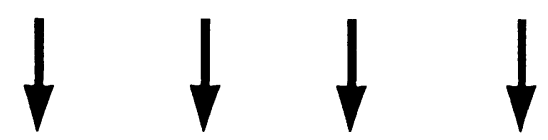

CARA TRATADA

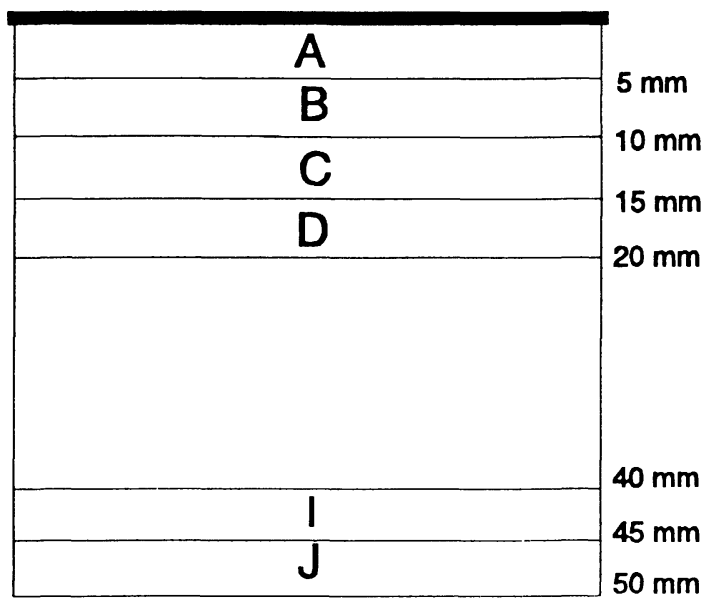

The numerical results obtained are presented in Table I and are represented graphically in Figure $8(a-d)$.
Fig. 7.-Esquema, sobre el alzado de una probeta, de los distintos cortes de piedra empleados para realizar las porosimetrias de mercurio.

Fig. 7.-Cutting scheme for mercury porosimetry samples.

TABLA I TABLE I

Valores de porosidad abierta de las rocas estudiadas en relación con el modo de aplicación del consolidante y la distancia a la cara tratada (Porosity values of the Hontoria and Laspra stones in relation to distance from the treated surface)

\begin{tabular}{|c|c|c|c|c|c|}
\hline & \multicolumn{2}{|c|}{ CALIZA DE HONTORIA } & \multicolumn{2}{|c|}{ DOLOMIA DE LASPRA } & \\
\hline \multirow{8}{*}{ 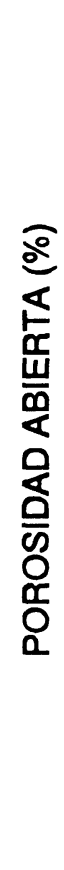 } & CAPILARIDAD & PINCEL & CAPILARIDAD & PINCEL & \\
\hline & 21.3 & 23.4 & 30.0 & 36.4 & NO TRATADA \\
\hline & 16.6 & 21.0 & 23.5 & 33.6 & A \\
\hline & 183 & 22.3 & 28.2 & 35.8 & B \\
\hline & & 23.3 & 30.1 & 36.5 & $\mathrm{C}$ \\
\hline & 18.8 & & & & D \\
\hline & 19.1 & & & & 1 \\
\hline & & & & & $J$ \\
\hline
\end{tabular}



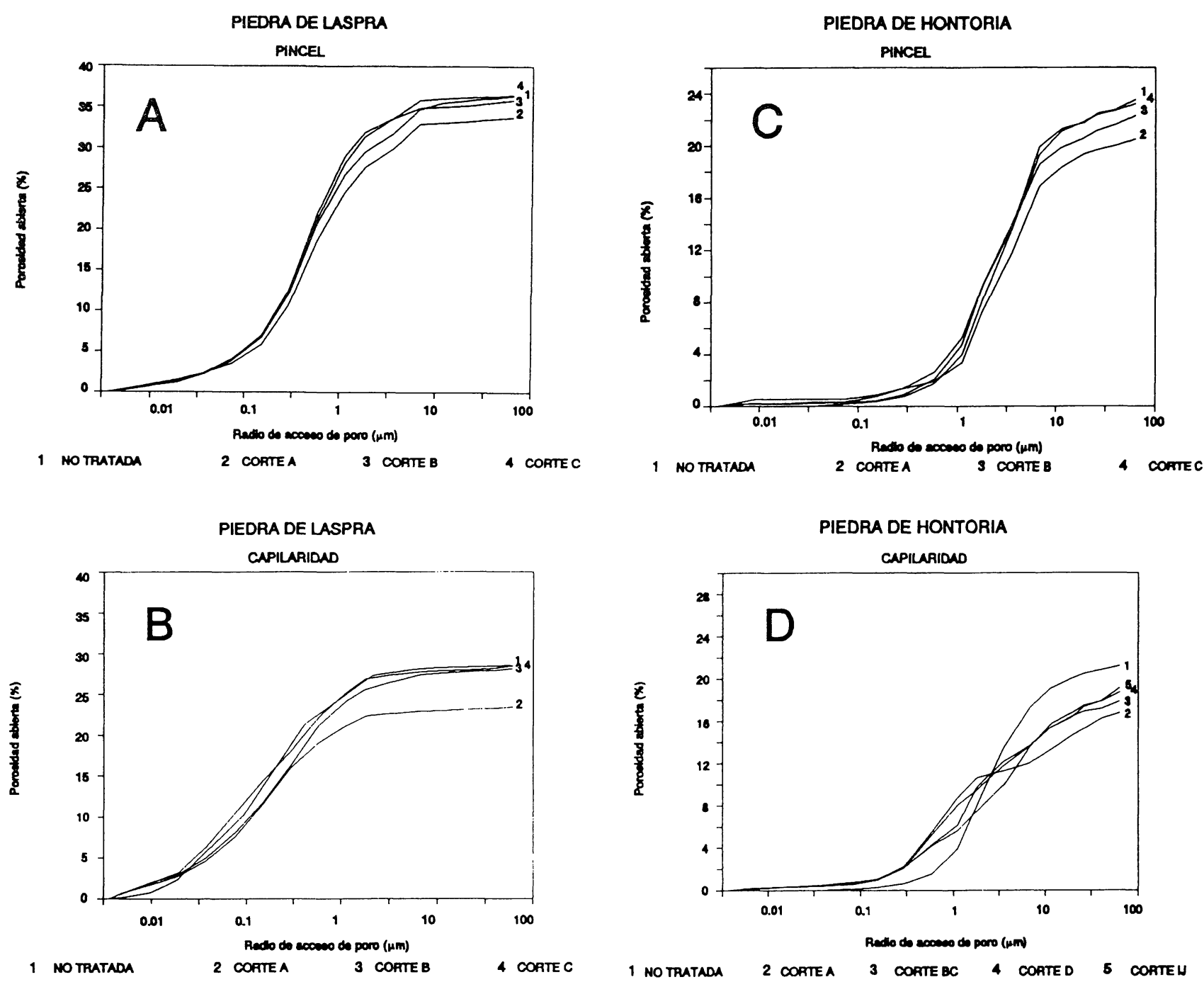

Fig. 8.-Curvas porométricas correspondientes a los distintos cortes ensayados de las piedras de Laspra (A y B) y Hontoria (C y D) sin tratar y tratadas con pincel y por capilaridad.

1: Curva correspondiente a la roca no tratada.

2: Curva correspondiente al corte $A(0-5 \mathrm{~mm})$.

3: Curva correspondiente al corte B $(5-10 \mathrm{~mm})$.

4: Curva correspondiente al corte $\mathrm{C}(10-15 \mathrm{~mm})$

5: Curva correspondiente al corte IJ $(40-50 \mathrm{~mm})$.

Fig. 8. - Porometric curves corresponding to the different slices carried out with the Laspra $(A$ and $B)$ and Hontoria stones $(C$ and $D)$ untreated and treated with brush and by capillarity.

1: Porometric curve corresponding to the untreated rock.

2: Porometric curve corresponding to the slice $A(0-5 \mathrm{~mm})$.

3: Porometric curve corresponding to the slice $B(10-15 \mathrm{~mm})$

4: Porometric curve corresponding to the slice $C(15-20 \mathrm{~mm})$.

5: Porometric curve corresponding to the slice IJ $(40-50 \mathrm{~mm})$.

\section{RESULTADOS}

\section{Dolomía de Laspra tratada con pincel}

La porosidad abierta (porosidad accesible al mercurio) de esta roca sin tratar es de un $36,4 \%$. En la figura 8 a donde se presentan las curvas

\section{RESULTS}

Laspra dolomite, treatment applied by brush

The open porosity (porosity accessible to mercury) of the untreated rock is $36,4 \%$. In Figure 8 a, in which porometric curves for different 
porométricas, obtenidas a distintas profundidades (cortes A, B y C), se observa cómo sólo en el corte A se registra una disminución del valor de la porosidad $\left(n_{0}=33,6 \%\right)$, con respecto al valor inicial. Esto indica que tan sólo los $5 \mathrm{~mm}$ más superficiales se encuentran afectados por el tratamiento.

Analizando las variaciones inducidas por el tratamiento en los radios de acceso de los poros, se aprecia cómo en la parte de roca afectada por el tratamiento (corte A) cambia la distribución porométrica, con relacción a la roca no tratada. Se detecta un aumento de los poros con radios de acceso menores a 0,05 micras, una disminución de los poros con accesos entre 0,05 y 15 micras y apenas modificación de los poros con accesos mayores de 15 micras.

El tratamiento ha tapizado pues los accesos con radios entre 0,05 y 15 micras y ha ocluido casi totalmente los menores a 0,05 micras.

\section{Dolomía de Laspra tratada por capilaridad}

En la tabla I se observa que la roca tiene una porosidad inicial del $30 \%$ y que en el corte A ha pasado a ser del $23,5 \%$. Se puede decir, al igual que ocurría en el tratamiento aplicado con pincel, que los cortes $\mathrm{B}$ y $\mathrm{C}$ presentan curvas porosimétricas prácticamente iguales a la de la roca no tratada (Fig. $8 b$ ).

Este mayor descenso de porosidad con respecto al detectado en el corte $A$ del tratamiento con pincel puede deberse, en este caso, bien a que el tratamiento colmata mucho más el sistema poroso inicial o bien a que en el caso anterior de la piedra tratada con pincel, éste no ha penetrado 5 $\mathrm{mm}$, sino menos. Esto no pueden detectarlo nuestras pruebas porosimétricas, por haber tomado espesores de $5 \mathrm{~mm}$.

Sea por lo que fuere, en este segundo caso se observa cómo en el corte A se produce una pérdida considerable de poros con accesos mayores de 1 micra. Por contra, los poros con accesos entre 1 y 0,05 micras aumentan con relacción a los de la piedra no tratada.

En el corte B, cuya porosidad es cercana a la de la roca no tratada $(28,2 \%)$ se aprecia un descenso en el porcentaje de poros con accesos mayores de 3 micras semejante al del corte $A$, pero para tamaños menores la pérdida de porosidad no es tan marcada.

Todo ello hace pensar que la mayor disminución de porosidad del corte A de la roca tratada por depths (slices $A, B$ and $C$ ) are presented it can be seen that only in slice $A$ is there a decrease in the porosity value ( to $33,6 \%$ ) compared with the initial value. This indicates that it is only the outermost $5 \mathrm{~mm}$ of the rock that is affected by the treatment.

Analysing the variations induced by the treatment in the pore throat radii, it can be observed that in the part of the rock affected by the treatment (slice $A$ ) there is a change in the distribution of pore sizes compared with the untreated rock. There is an increase in the number of pores with throat radii of less than $0,05 \mu \mathrm{m}$. and little change in the number of pores with throat radii greater than $15 \mu \mathrm{m}$.

The treatment has partially closed the pores with radii of between 0,05 and $15 \mu \mathrm{m}$ and has almost totally sealed those less than $0,05 \mu \mathrm{m}$.

\section{Laspra dolomite, treatment applied by capillarity}

In Table I, it can be observed that the rock has an initial porosity of $30 \%$ and that, in slice $A$, the value is reduced to $23,5 \%$. As in the case of the treatment applied by bruch, slices $B$ and $C$ show porosimetric curves that are practically the same as that for the untreated rock (Figure $8 b$ ).

The decrease in porosity observed in slice $A$ is greater in this case than in the case of the treatment applied by brush, either because the pores are filled more effectively or because the application by brush only affects a zone much less than $5 \mathrm{~mm}$ in depth. This cannot be confirmed by the tests carried out here, which have been on $5 \mathrm{~mm}$ slices.

In this second case, it can be observed that in slice $A$ there is a considerable decrease in the number of pores with throat radii greater than $1 \mu \mathrm{m}$. In contrast, there is an increase in the number of pores with troat radii between 1 and $0,05 \mu \mathrm{m}$ compared with the untreated rock.

In slice $B$, the porosity of which is close to that of the untreated rock (28,2 \%), there is an apreciable decrease in the percentage of pores with throat radii greater than $3 \mu \mathrm{m}$ similar to the case of slice $A$, but for smaller sizes the decrease is less marked.

Consequently, it would be deduced that the greater porosity degrease in slice $A$ of the rock 
capilaridad, con respecto a la tratada con pincel, sea consecuencia más a la mayor tasa de relleno de poros que de una mayor penetración del tratamiento en este segundo caso.

\section{Caliza de Hontoria tratada con pincel}

Esta roca no tratada presenta una porosidad del $23,4 \%$ (Tabla I). Cuando se trata, el citado valor no se recupera hasta llegar al corte $C(10-15 \mathrm{~mm}$ de la superficie tratada), como se constata en la figura 8c, donde se observa que las curvas porosimétricas correspondientes al corte $\mathrm{C}$ y a la roca no tratada, son coincidentes.

Además el tratamiento aplicado de este modo, no afecta apenas a los poros con radios de acceso superiores a las 15 micras. Sin embargo, sí que se presentan otros cambios significativos en la geometría del sistema poroso. Así, la parte más superficial tratada (corte A) presenta una gran reducción de poros con tamaños entre 1 y 15 micras, descenso observable también en el corte $B$, aunque de manera menos acusada. Por contra, los poros con accesos menores de 1 micra aumentan significativamente en los cortes $A$ y $B$, hasta el punto de que aparecen poros con accesos menores de 0,3 micras, inexistentes en la roca no tratada y que tampoco aparecen en la curva porosimétrica correspondiente al corte $\mathrm{C}$. Estos "nuevos poros" son el resultado de la oclusión parcial, por parte del tratamiento, de poros inicialmente mayores.

\section{Caliza de Hontoria tratada por capilaridad}

El valor de la porosidad en la piedra no tratada es del 21,3\% (Tabla I); una vez tratada, dicha porosidad no se recupera ni siquiera en los cortes más alejados de la superficie de aplicación (corte IJ). Esto indica que toda la probeta $(5 \times 5 \times 5 \mathrm{~cm})$ ha sido afectada por el tratamiento aplicado, lo que se constata en las curvas porosimétricas de la figura $8 \mathrm{~d}$.

Las variaciones inducidas por el tratamiento, en la configuración del sistema poroso, podrian traducirse del siguiente modo: los poros entre 70 y 25 micras aumentan con respecto a los de la piedra no tratada, lo cual se interpreta como debido al cierre parcial de poros con accesos mayores de 70 micras que, por ello, en la roca no tratada estaban fuera del campo de detección del porosímetro de mercurio.

Disminuye el porcentaje de poros con radios de acceso entre 15 y 3 micras. Este hecho se atenua treated by capillarity in relation to the one treated with brush, in more a result of the greater rate of pore filling than of a greater penetration of the treatment in the latter.

\section{Hontoria limestone, treatment applied by brush}

The untreated hontoria limestone has a porosity of $23,4 \%$ (Table I). In the treated rock, this value does not recover until slice $C(10-15 \mathrm{~mm}$ from the treated surface), as is shown in Figure $8 c$, where it can be observed that the porosimetric curves corresponding to slice $C$ and the untreated rock are coincident.

Moreover, the treatment applied by brush hardly affects the pores with throat radii greater than $15 \mu \mathrm{m}$. Nevertheless, other significant changes are observed in the pore system. Thus, the rock nearest the treated surface (slice A) shown a great reduction in the number of pores with sizes between 1 and $15 \mu \mathrm{m}$, a decrease which is also observed in slice $B$ although less obviously. in contrast, the pores with throat radii of less than 1 $\mu m$ increase significantly in slices $A$ and $B$ up to the point at which appear pores with throat radii of less than 0,3 $\mu \mathrm{m}$, which do not exist in the untreated rock and which do not appear in slice $C$ either. These "new pores" are the result of the partial sealing of originally larger pores by the treatment solution.

\section{Hontoria limestone, treatment applied by capillarity}

The porosity of the untreated stone is $21,3 \%$ (Table I), a value which does not recover even in the sample slices most distant from the treated surface (slices I and J). This indicates that the whole sample cube $(5 \times 5 \times 5 \mathrm{~cm})$ has been affected by the treatment process, as shown in the curves of Figure 8d.

The variations in the pore geometry induced by the treatment can be interpreted as follows: the pores with throat radii between 70 and $25 \mu \mathrm{m}$ increase compared with the untreated rock dure to the partial closure of pores with throat radii greater than $70 \mu \mathrm{m}$, which were beyond the limit of detection of the mercury porosimetry in the untreated rock.

The percentage of porco with threat between 15 and $2 \mu \mathrm{m}$ decreases in the treated rock. This 
con la profundidad (hacia el corte IJ). En cuanto a los poros menores de 1 micra les ocurre lo contrario, aumentan su porcentaje relativo en la roca tratada respecto a la no tratada y es en el corte A donde dicho porcentaje es mayor. En los poros con accesos menores de 0,2 micras la tendencia en profundidad no es muy clara.

\section{CONCLUSIONES}

Se ha comprobado experimentalmente que, la mayor o menor penetración de un producto de tratamiento consolidante de naturaleza sílicoorgánica — silicato de etilo- en una roca, está relacionado más con el tamaño y grado de comunicación de los espacios vacios de la misma, que con su número (porosidad).

El modo de aplicación del producto influye asimismo en su grado de penetración. Así, en la caliza de Hontoria el tratamiento aplicado con pincel penetra sólo $15 \mathrm{~mm}$, frente a los más de $50 \mathrm{~mm}$ alcanzados por capilaridad. En la dolomía de Laspra, las diferencias de penetración no están tanto en la profundidad como en el grado de relleno del sistema poroso, ya que para ambos modos de aplicación la penetración alcanzará sólo unos $5 \mathrm{~mm}$.

En todos los casos el producto de tratamiento aplicado cambia la geometría del sistema poroso en la parte de la piedra a la que afecta.

Este hecho, constatado experimentalmente, permite afirmar que estos cambios inducidos por el tratamiento en la geometría del sistema poroso comportarán cambios en la: absorción, desorción y succión capilar de agua; en la permeabilidad al vapor, etc., es decir, en los movimientos del agua por el interior de la piedra. Esto, a su vez, condicionará la alterabilidad del sistema piedratratamiento.

\section{AGRADECIMIENTOS}

A la Comisión Interministerial de Ciencia y Tecnología (CICYT), Proyecto PAT91-1093-CO301: "Modelos de interacción piedra-ambiente para el diagnóstico del deterioro de la piedra monumental".

\section{A la Consejeria de Cultura y Turismo de la Junta de Castilla y León, Contrato B1-038-92: "Incidencia del ambiente en el deterioro de la piedra de Hontoria en la Catedral de Burgos: Cimborrio y Fachada de la Coronería".}

effect diminishes with depth (towards slices I and $J)$. Pores smaller than $1 \mu \mathrm{m}$ show the opposite trend, increasing in the treated rock compared with the untreated rock, notably in slice $A$, even though the trend is less clear for pores with throat radii of less than $0,2 \mu \mathrm{m}$.

\section{CONCLUSIONS}

It has been verified wxperimentally that the greater or lesser penetration into a rock material of a silico-organic consolidant (ethyl silicate) is related more to the size and interconnectivity of the voids in the rock than to their number (porosity).

The mode of application of the product also influences the penetration. Thus, in the Hontoria limestone, the treatment applied by brush penetrates only $15 \mathrm{~mm}$ compared with more than $50 \mathrm{~mm}$ reached by capillarity. In the Laspra dolomite, the difference are not so much in the depth of penetration as in the degree of infilling of the pore system, since for both application systems the penetration will only reach about $5 \mathrm{~mm}$.

The treatment product applied changes the geometry of the pore system in the part of the rock affected.

The results confirm that the changes induced by the treatment in the pore system produce changes in the absorption, desorption and capillary suction of water, in the permeability to water vapour, etc.; that is, in the movement of water within the interior of the rock. This will influence, in turn, the susceptibility to alteration of the rock-treatment system.

\section{ACKNOWLEDGEMENTS}

The support of the Comision Interministerial de Ciencia y Tecnología (CICYT), Project No. PAT91-1093-CO3-01: "Modelos de interacción piedra-ambiente para el diagnóstico del deterioro de la piedra monumental", is gratefully acknowledged.

Thanks are also due to the Consejeria de Cultura y Turismo de la Junta de Castilla y León, Contract No. 31-038-92. "Incidencia del ambiente en el deterioro de la piedra de Hontoria en la Catedral de Burgos: Cimborrio y Fachada de la Coronería". 


\section{BIBLIOGRAFIA}

(1) ESBERT, R. M.; GROSSI, C. y MARCOS, R. M. (1987a y b): Estudios experimentales sobre la consolidación y protección de los materiales calcáreos de la Catedral de Oviedo. $1^{\underline{a}}$ y $2^{\underline{a}}$ partes. Materiales de Construcción, 206 y 208, Instituto Eduardo Torroja, Madrid.

(2) MARCOS, R. M. (1992): Tratamientos de conservación aplicados a rocas carbonatadas: Catedral de León. Tesis Doctoral. Dpto. de Geología, Area de Petrología, Univ. Oviedo. 150 p.

(3) PELLERIN, F. M. (1980): La porosimétrieau mercure appliquée à l'etude géotechnique des sols et des roches. Bull. Liaison Lab. des Ponts et Chaussées, 106, pp. 105-116.

(4) ESBERT, R. M. y MARCOS, R. M. (1983): Las piedras de la Catedral de Oviedo y su deterioración. Publ. Colegio Oficial de Aparejadores y Arquitectos Técnicos de Asturias, Oviedo, $144 \mathrm{p}$.

(5) ESBERT, R. M.; GARCIA-RAMOS, J. C.; NISTAL, A. M.; ORDAZ, J.; VALENZUELA, M.; ALONSO, F. J. y SUAREZ de CENTI, C. (1992): El proceso digital de imágenes aplicado a la conservación de la piedra monumental. Un ejemplo: Santa $M^{a}$ del Naranco. Revista de Arqueología, 139, Madrid, pp. 7-11.

(6) GROSSI, C. (1986): Ensayos de tratamiento en materiales rocosos de la Catedral de Oviedo. Tesis de Licenciatura. Dpto. de Petrología y Geoquímica, Univ. de Oviedo. 122p.

(7) HAMMECKER, C.; ESBERT R. M. y JEANNETTE, D. (1992): Geometry modifications of porous network in carbonate rocks by ethyl silicate treatement. 7th International congress on deterioration and conservation of stone, vol 3, Lisboa, pp. 1053-1081.

(8) ALONSO, F. J. (1986): Caracterización petrofísica y alterabilidad de calizas y dolomías. Tesis Doctoral, Dpto. Petrología, Fac. Geología, Univ. Oviedo. 309 p.

(9) BRAKEL, J. van; MODRY, S. Y SVATA, M. (1981): Mercury porosimetry: state of the art. Powder Thechnology, 29 (1), pp. 1-12.

(10) BOUSQUIE, P. (1979): Texture et porosité de roches calcaires. Tesis, Univ. Pierre et Marie Curie, Paris VI, 191 p.

(11) WARDLAW, N. C. y MC KELLAR, M. (1981): Mercury porosimetry and the interpretation of pore geometry in sedimentary rocks and artificial models. Powder technology, 29 (1), pp. 127-143.

\section{publicación del ICCET/CSIC}

\section{INSPECCION DE OBRAS DAÑADAS POR CORROSION DE ARMADURAS}

El presente Manual va dirigido principalmente a técnicos especializados y laboratorios que tienen que intervenir en el dictamen de la situación de deterioro de estructuras de hormigón armado dañadas por corrosión de armaduras.

Comienza con un resumen recordatorio de los factores principales a los que se pueden deber los daños prematuros por corrosión de armaduras, para seguir con algunas indicaciones de cómo se deben realizar las inspecciones, y de los ensayos y la metodología que se recomienda realizar para poder dictaminar con precisión las causas de daño.

A continuación se hacen una serie de comentarios sobre la vida residual de estructuras dañadas, sobre el riesgo de corrosión futura, el seguimiento necesario de una estructura reparada y una breve enumeración de métodos de reparación y consideraciones básicas a tener en cuenta en la recomendación de un determinado método. Se aporta una breve relación bibliográfica.

Finalmente se incluyen en forma de ficha la descripción de algunos casos de corrosión de armaduras detectados en nuestro país.

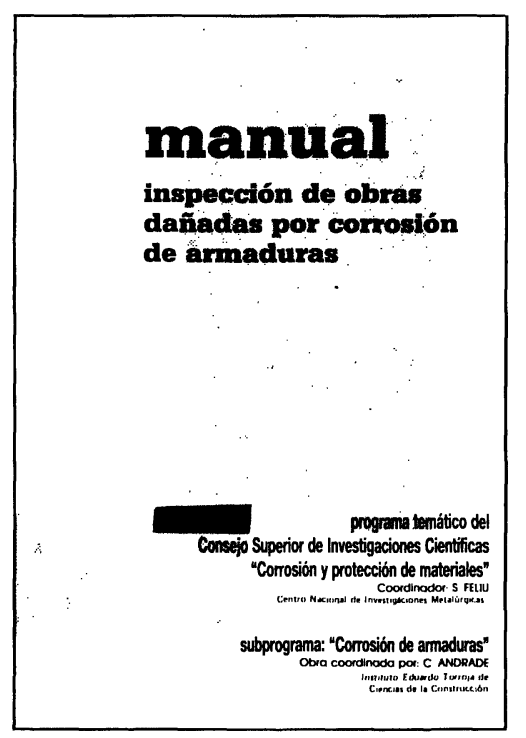

